\title{
Sekapur Sirih
}

\section{SYUKUR DALAM WACANA PSIKOLOGI}

Beberapa tahun belakangan, wacana tentang gratitude (sering diartikan kebersyukuran, kesyukuran) semakin marak, baik di Indonesia maupun di mancanegara. Hal ini terlihat dari banyaknya kajian dan penelitian terkait dengan topik kebersyukuran. Salah satu hasil penelitian tentang kebersyukuran ditampilkan dalam Jurnal Intervensi Psikologi edisi ini. Di sini ditampilkan hasil penelitian bertajuk Peningkatan Syukur Penduduk Miskin Melalui Intervensi Pelatihan Syukur yang ditulis oleh Anggarani, Andayani dan dan Karyanta (2013). Peterson dan Seligman (2005) adalah dua di antara banyak ahli yang membahas topik ini. Mereka menulis buku Character Strength and Virtue. Dalam buku itu mereka menampilkan kebersyukuran (gratitude) sebagai salah satu karakter positif di antara 24 karakter positif manusia. Ahli lain berinovasi dengan menampilkan apa yang mereka sebut sebagai gratitude therapy.

Menarik untuk diperhatikan bahwa ternyata ada pemahaman yang begitu beragam terhadap apa yang disebut sebagai kebersyukuran. Konsep kebersyukuran ternyata dipahami para ahli dengan menggunakan berbagai pendekatan, baik pendekatan agama, pendekatan sekuler, maupun integrasi di antara keduanya. Konsep kebersyukuran yang ditampilkan Anggarani, Andayani dan dan Karyanta (2013) misalnya mengacu kepada pendekatan psikologi kontemporer yang sekularistik. Hal ini memunculkan pertanyaan kritis, cocokkah pendekatan sekuler digunakan untuk masyarakat yang religius?

\section{Indikator Kebersyukuran}

Syukur dalam pandangan Islam dan sains Barat memiliki makna yang berbeda. Seorang ahli Islam, yaitu Al-Munajjid (2006), mengartikan kebersyukuran sebagai berterima kasih kepada pihak yang berbuat baik atas kebajikan yang telah diberikannya, dalam hal ini kepada Tuhan sebagai pemberi dan kepada makhluk yang menjadi perantaranya. Berbeda dengan perspektif Islam, ahli psikologi yang sekularistik, salah satunya Watkins dkk (2003), mengartikan kebersyukuran (gratitude) adalah sifat afektif yang mengacu kepada seberapa besar individu mengalami perasaan apresiasi atas nikmat yang diperolehnya. Al-Munajjid meletakkan Tuhan sebagai pihak yang dipandang sebagai sumber syukur. Watkins dkk tak mengaitkan apresiasi nikmat dengan Tuhan.

Dampak dari perbedaan pengertian di atas adalah perbedaan indikator kebersyukuran. Watkins dkk (2003) menunjukkan bahwa indikator kebersyukuran terdiri 
atas (1) perasaan berkelimpahan, (2) mengapresiasi kontribusi orang lain, (3) menghargai kesenangan sederhana, dan (4) mengekspresikan rasa terima kasih. Sementara itu, dalam perspektif Islam sebagaimana mengacu kepada hadits Nabi Muhammad saw, indikator syukur meliputi (1) syukur dalam hati, (2) syukur secara lisan kepada Allah, (3) syukur secara kepada sesama makhluk, dan (4) syukur dalam bentuk perbuatan.

Mencoba mengintegrasikan pandangan agama dan sains yang sekuler, Peterson dan Seligman (2005) menerjemahkan kebersyukuran (gratitude) dengan dua indikator, yaitu (1) sadar dan bersyukur atas anugerah Tuhan dan (2) menyediakan waktu untuk mengekspresikan rasa bersyukur.

\section{Konteks Indonesia}

Salah satu pertimbangan para peneliti saat menggunakan pendekatan adalah kesesuaiannya dengan konteks agama dan budaya. Indonesia bisa dipahami sebagai bangsa yang memiliki religiositas yang cukup tinggi. Semua warga negara Indonesia adalah beragama tertentu dengan pemeluk Islam menjadi mayoritas sekitar $88.5 \%$. Tidak kurang dari itu, Indonesia juga dapat dipahami dalam konteks budaya yang menekankan kolektivistik. Dalam budaya yang kolektivistik setiap perbuatan individu memiliki keterkaitan dengan orang lain.

Kritik yang dapat diberikan terhadap tulisan Ilham dan Andayani (2014) adalah apakah ia sesuai dengan konteks budaya dan agama subjek penelitian? Konteks keindonesiaan dan keislaman sangat penting dalam pengukuran kebersyukuran. Kalau kebersyukuran dikontekskan dengan warga negara Indonesia yang memandang penting agama, maka konstruk yang dapat dipakai untuk memahami masyarakat Indonesia semestinya adalah yang sesuai dengan ajaran agama yang dianut oleh warganegara. Konstruk Al-Munajjid (2006) tampaknya lebih sesuaidigunakan untuk konteks masyarakat Indonesia dibanding konstruk Watkins dkk (2003).

Demikian. Wallahu a'lam bi ash shawab.

H. Fuad Nashori

Email: fuadnashori@yahoo.com 